\title{
Policy Frameworks Supporting Africa- Europe STI Cooperation: Past Achievements and Future Responsibilities
}

Ismail Barugahara and Arne Tostensen

\begin{abstract}
This chapter provides an overview of the chronological developments of the Africa-Europe cooperation on science, technology and innovation (STI). The authors first remind readers that African-European cooperation bears the mark of the prior colonisation of the African continent and the deep establishment of unequal and (geographically) unbalanced cooperation patterns. They then reflect on the renewed interest in STI in Africa-Europe cooperation. The chapter explains how more balanced cooperation structures and more efficient financing systems can be achieved and how science can become an integrated part of global development strategies.
\end{abstract}

Keywords Framework programme - Africa-Europe economic agreements - International cooperation strategy - Sustainable cooperation • Global development $\bullet$ STI cooperation

I. Barugahara $(\bowtie)$

National Council for Science and Technology, Kampala, Uganda

A. Tostensen

Research Council of Norway and Chr. Michelsen Institute, Bergen, Norway

(C) The Author(s) 2018

A. Cherry et al. (eds.), Africa-Europe Research and Innovation

Cooperation, https://doi.org/10.1007/978-3-319-69929-5_2 


\section{INTRODUCTION}

Science, technology and innovation (STI) cooperation between Europe and Africa has undergone significant change in the past decade. For example, by September 2013, towards the close of the EU's Seventh Framework Programme (FP7), there were 1315 participants from 45 African countries in 565 projects, with a total grant funding of 178 million euros from the European Commission (EC). About $82 \%$ of these projects received financing mainly through the FP7 "Cooperation Specific Programme" and were largely centred on health, agri-food and the environment.

The adoption in 2007 of the Joint Africa-EU Strategy (JAES) prepared the ground for partnerships based on egalitarian relationships and mutual benefits while acknowledging the critical role STI can play in boosting both human and socio-economic development (African Union \& European Union 2007a). Nevertheless, cooperative efforts must be strengthened. More particularly, both European and African countries must continue to join forces to further align STI cooperation politics, harmonise their monitoring instruments and better coordinate their programmes.

This chapter first describes the prominent regional and bi-regional policy frameworks that underpin Africa-Europe cooperation on STI. Our chronology of Africa-Europe cooperation begins in 1957 (with the Treaty of Rome) and continues to more recent developments, with the adoption, in 2007, of the JAES and the establishment of a bi-regional partnership on food, nutrition security and sustainable agriculture (FNSSA) in 2016. It then focuses on two key issues that Africa-Europe STI cooperation is currently facing: first, the necessity to find new models for more equitable and sustainable funding of STI in Europe and Africa alike; and second, the need for continuous efforts to prioritise science and technology in the global development agenda (Agenda 2030). This chapter argues that if policymakers do not give these issues earnest consideration, cooperation risks not only forgoing the important gains it has made but also faces the risk of being weakened.

\section{The Policy Frameworks}

\section{The Cotonou Agreement}

In 1957, in the context of both African decolonisation and the early stages of building the modern-day European Union (EU), the Treaty of Rome made a provision for the creation of a European Development Fund (EDF) 
with a view to granting technical and financial assistance to African countries, some of which at that time were still colonies of European powers. The Cotonou Agreement paved the way for greater Africa-Europe cooperation in broad terms and, until today, serves as an umbrella under which many funding instruments fall. Preceded by the four successive Lomé Conventions (Lomé I-IV), the Cotonou Agreement was concluded in 2000 for a 20 -year period as a partnership between the EU and 79 countries of the African (excluding South Africa), Caribbean and the Pacific (ACP) regions. Its fundamental principles include the equality of the partners, as well as inclusive participation, dialogue and regionalisation.

The Cotonou Agreement was revised in 2005 and 2010 and now rests on three pillars, namely, development cooperation, political cooperation, and economic and trade cooperation. The 2010 revision was particularly significant because it recognised climate change as a global challenge, committing the parties to include it in development cooperation and to support ACP efforts in mitigating and adapting to the effects of climate change. This revision was also instrumental in putting into practice the internationally agreed aid effectiveness principles laid down in the Paris Declaration, especially the principle of donor coordination.

Although the EDF falls outside the EU's Multiannual Financial Framework (MFF), it is the main source of funding under the Cotonou Agreement, and mainly directed to development cooperation with African governments, either through national programmes or through Africa's Regional Economic Communities (RECs). Financed by direct contributions from EU member states according to contribution shares (or "keys"), it is governed by its own rules. The current $11^{\text {th }}$ EDF has 30.5 billion euros at its disposal for the period 2014-2020. The EDF operates thematic development cooperation programmes in areas such as health and the environment as well as programmes with a pan-African focus. While the EDF covers all ACP countries, the large number of African states forms a majority. A few national or regional activities funded by the EDF have a specific science and technology capacity building orientation.

\section{The European Consensus on Development}

The European Consensus on Development (ECD), adopted in 2006, formed the common basis of EU development policies and actions. The ECD was adopted in March 2005, aiming at eradicating poverty and promoting sustainable development. In-depth political dialogue was set out as an essential ingredient for good governance, the respect of human 
rights and the rule of law, the fight against corruption and spread of democratic rule. Furthermore, to address the problems of fragile states, the EU pledged to engage in institution building and to foster linkages between emergency aid, rehabilitation and long-term development.

The ECD reiterated its support for global initiatives such as the Millennium Development Goals (MDGs) - today replaced by the Sustainable Development Goals (SDGs) — covering key development issues such as poverty, health, food security, access to education, gender equality and environmental sustainability, and which emphasised the need of a global partnership for development. Just like the MDGs, the SDGs involve various sectoral and thematic domains of STI, whose advancement and application are implicated in their realisation. At the same time, it reaffirmed the need to coordinate with the Bretton Woods institutions' policies and programmes and to enhance cooperation with the United Nations (UN) system and other relevant institutions such as the Development Assistance Committee of the Organisation for Economic Co-operation and Development (OECD), especially the Good Practice Guidelines of the latter.

In terms of the volume of resources put at the disposal of development partners, the EU adopted a timetable for its member states to reach the $0.7 \%$ of gross national income (GNI) goal by 2015 , with an intermediate collective target of $0.56 \%$ by 2010 . If these targets had been achieved, it would have doubled EU development assistance to 66 billion euros by 2010. Although failing to achieve these targets, the EU has remained a major development partner for Africa. From 2007 until 2013, official development assistance in the form of national budget and project support disbursed to Africa by the EU and its member states was estimated at 144 billion euros, or about 20.6 billion euros on average per year (European Commission 2016c). The EU is committed not only to providing aid (with efficiency and quality) but also to entering into economic and trading partnerships with developing countries. It is worth mentioning that although the ECD did not prioritise STI cooperation, it has remained open, in principle, to such a collaboration.

\section{Consolidated Plan of Action (2006-2014)}

Africa's Science and Technology Consolidated Plan of Action (CPA) was adopted in 2005 to promote and use science and technology to foster socio-economic development and ensure Africa's integration into the world economy (NEPAD 2006). At the time of its formulation, the 
African continent had made only modest progress in the area of STI, owing to numerous systemic constraints: weak inter-institutional linkages and collaboration; disjointed STI and development policies; weak policy implementation capacity; modest national allocations for science and technology (below 1\% of gross domestic product (GDP)); as well as a limited capacity to translate research results into industrial products and services (Barugahara and Tostensen 2009a).

To address these challenges, the CPA established three priority areas: capacity building, knowledge production (as well as scientific research) and technological innovation. The following goals were set: (1) implementing the African Science, Technology and Innovation Indicators Initiative; (2) improving regional cooperation in STI (through capacity building, exchange of good practices, the formation of a common African framework for cooperation in science and technology, and a more active participation in EU facilities); (3) building a public understanding of STI; (4) building a common African strategy for biotechnology; (5) building science and technology policy capacity; (6) creating technology parks.

The CPA was implemented through networks of centres of excellence, which were dedicated to specific STI and capacity building programmes, while complementing other African Union (AU) and New Partnership for Africa's Development (NEPAD) specific programmes for agriculture, environment, health infrastructures, industrialisation and education. The AU Commission (AUC) provided overall political and policy leadership for the implementation of the CPA, while the NEPAD office for science and technology and the African Ministerial Council on Science and Technology (AMCOST) provided overall technical and intellectual leadership.

The CPA successfully managed to raise awareness among many African governments about the usefulness of STI in societal transformation and development processes. It also unified the so-far fragmented national systems of innovation (NSI) of the countries that had jointly formulated STI priorities. While the CPA was elaborated to address STI challenges in Africa, it was acknowledged, very early on, that a more thorough engagement with the EU would be advantageous to achieve its ambitious goals. Such engagement encompassed professional collaboration in research and innovation (R\&I) activities, but also funding and capacity building in prioritised fields (Barugahara and Tostensen 2009a, p. 44). 


\section{Science, Technology and Innovation Strategy for Africa (STISA-2024) (2014-Present)}

In 2014, the AU further committed itself to support STI policies and, in so doing, set up the Science, Technology and Innovation Strategy for Africa (STISA-2024), which was to replace the CPA. STISA-2024 was adopted during the $23^{\text {rd }}$ Ordinary Session of the AU Executive Council during the AU Summit held in Malabo, Equatorial Guinea, and served as the continental framework for accelerating Africa's transition to an innovation-led, knowledge-based economy (EX.CL/839[XXV]). As an integral part of the Agenda 2063 set by the AUC, which recognised STI as a major driving force for socio-economic development, STISA-2024 was designed as a ten-year incremental strategy and emphasised the necessity to integrate STI into critical sectors such as agriculture, health, infrastructure development, mining, water, energy, and environment. Its six key priority areas included (1) eradication of hunger and achieving food security, (2) prevention and control of diseases, (3) communication, (4) protection of our space, (5) Living Together-Building the Society and (6) wealth creation. The meeting specifically called upon African states and the RECs to integrate STISA-2024 into their STI development agendas for implementation.

\section{The EU's International Scientific Cooperation Strategy}

International cooperation is expected to foster new knowledge production, increase scientific quality and improve the competiveness of R\&I systems. At the same time, internationalisation boosts the productivity of investments in research and development by enabling companies to gain more knowledge from international markets, to participate in new value chains and reap greater benefits from growing markets outside the EU (European Commission 2016c).

Premised on the above expectations, in 2012, the EU adopted a strategy for international cooperation in R\&I. The main objectives of the strategy are to strengthen the EU's R\&I excellence, attractiveness and economic and industrial competitiveness, tackling global societal challenges, and supporting the EU's external policies. The research programmes carried out by the EU are open to participation by research institutions and researchers worldwide and cooperation is fostered through FPs for R\&I (currently Horizon 2020). The EU is also developing 
targeted strategies with specific countries in order to achieve specific objectives: in 2015 the European Commission published 11 multiannual roadmaps for scientific cooperation with industrialised countries (Canada, South Korea, USA, Japan), emerging scientific powers (Brazil, Russia, India, China, South Africa) and the European Neighbourhood Policy countries in two groups (Eastern Partnership and Southern Mediterranean). Each roadmap presents the state of cooperation with the EU and defines thematic priorities for future cooperation in R\&I (European Union 2015). Several other roadmaps with third countries, especially countries in Africa, have since been published.

As a result, R\&I cooperation has been prioritised and intensified with the aim of making the EU a stronger global actor in solving global challenges in the areas of health, food, energy, water and climate change. Notably, the results of the EU's R\&I efforts have contributed to the development and implementation of a number of international commitments such as the United Nations Framework Conditions on Climate Change, the Convention on Biological Diversity, the 2030 Agenda for Sustainable Development and various resolutions of the World Health Organization. More than 1000 publications from FP7 projects contributed to the fifth Assessment Report of the Intergovernmental Panel on Climate Change that provided the evidence base for negotiations at the UN Climate Change Conference held in Paris in 2015 (European Commission 2016c).

\section{The Joint Africa-EU Strategy (2007-Present)}

From a starting point of largely separate continental approaches to STI strategies, the JAES specified the terms of engagement between the two continents, aiming to strengthen political partnership and cooperation. The JAES' Eighth Partnership on Science, Information Society and Space (also discussed in Chap. 1) specifically recognised STI as necessary to fostering knowledge-based societies, competitive economies and sustainable development. The JAES policy framework came with a first action plan (2008-2010), later succeeded by a second one (2011-2013) reinforcing the commitments on STI, and reiterating the strategic importance of modern technologies to achieve the MDGs, and the SDGs subsequently, set up by the UN 2030 Agenda (African Union \& European Union 2007b, 2010). 
In 2014, the Fourth EU-Africa Summit reaffirmed that the JAES continues to frame continent-to-continent cooperation. On the same occasion, a roadmap for 2014-2017 was adopted for the implementation of the joint strategy, and redefined the priority areas as (1) peace and security; (2) democracy, good governance and human rights; (3) human development; (4) sustainable and inclusive development and growth and continental integration; (5) global and emerging issues. The third priority area concerned STI more specifically, while the roadmap made an unequivocal case for its role in shaping the relations between the two continents: "Investments in science, technology and innovation (STI) are vital to promote growth and employment, improve competitiveness and tackle pressing global challenges" (EU-Africa Summit 2014). The Summit also recognised the EU-Africa High Level Policy Dialogue (HLPD) on STI as an instrumental actor in the implementation of the STI part of the programme. Most recently, in April 2016, the College-to-College meeting between the European Commission (EC) and the AUC reaffirmed its commitment to continued collaboration to maximise the mutual benefits of STI towards addressing multiple challenges, including poverty (European Commission 2016a, b, c).

The inclusion in the JAES of STI cooperation reinforces the wide range of collaborative relationships that exist outside of the bi-regional policy framework. These include the relations between the EU and/or its member states with sub-continental groupings such as the RECs. Several European states have maintained long-standing relationships of significant magnitude with African counterparts, under the Commonwealth or similar groups. The rapidly changing global scientific, technological, socioeconomic and political landscape has motivated current efforts towards the strengthening of the EU-Africa partnership.

All of these efforts have shaped the agenda for the Fifth Africa-EU Summit, which is scheduled for November 2017 with the aim to review and deepen the Africa-EU partnership. In the Joint Communication to the European Parliament and the Council for a renewed impetus of the Africa-EU Partnership, the EU proposes a revitalised framework for joint action. It sets out policy priorities and concrete initiatives for 2018-2020 and beyond, to be developed jointly with African partners, in response to Africa's Agenda 2063 and building on the Global Strategy for the EU's foreign policy (European Commission 2017).

The quest for a strengthened Africa-EU partnership is based on shared values and interests enshrined in the JAES. It is also based on a thriving 
long-term partnership where the EU remains Africa's significant development partner as illustrated by the following indicators: (1) the EU is collectively Africa's main foreign investor (32 billion euros of EU Foreign Direct Investments (FDI) flowed to Africa in 2015 (33\% of total FDI flows to Africa); the EU accounted for $33.5 \%$ of Africa's imports and $42 \%$ of Africa's exports in 2016-the European Investment Bank (EIB) also provides over 2 billion euros of annual financing in Africa; (2) the EU is Africa's main trading partner, offering free access to the EU market for all products via Economic Partnership Agreements, the Free Trade Agreements and the Union's Generalised Scheme of Preferences; (3) the EU is the main source of remittances (21 billion euros of remittances from Europe to Africa in 2015 [ $36 \%$ of global flow to Africa]); (4) the EU is the first partner in development and humanitarian assistance (21 billion euros of collective Official Development Assistance (ODA) [EU and its member states]) to Africa in 2015 (50\% of total ODA to Africa) (European Commission 2017).

Building on these concrete achievements, the EU suggested the JAES (2018-2020) should focus more strongly on sustainable and inclusive economic development in Africa by creating jobs and highlighting the opportunities it offers to Europe. The proposed flagship actions on R\&I cooperation include: (1) launching a new EU-Africa R\&I partnership on climate change and sustainable energy focusing on deployment as well as capacity building in renewable energy and energy efficiency and in climate services; (2) generating EU and African investments to support R\&I in agriculture via the EU-Africa Research and Innovation Partnership on FNSSA as well as increase the uptake of new technologies by local communities for increased agricultural income and nutrition; (3) intensification of Africa-EU collaboration on research by (i) facilitating collaboration between researchers and innovators from Africa and Europe, including through increasing professional development opportunities for researchers through the Marie Sklodowska-Curie Actions and other types of Horizon 2020 projects, (ii) supporting research capacity building in Africa through programmes such as the AURG, and (iii) supporting an open digital research environment for universities and research organisations. These are plausible actions that when concretised and implemented will strengthen Africa-EU R\&I cooperation and put both continents on a higher trajectory of development. 


\section{Three Key Policy Issues}

\section{Re-balancing Cooperation}

There is robust evidence worldwide that greater use of technology is a major factor in enhancing productivity-driven growth and industrial competitiveness (Solow 1956; Temple 1999; Barro and Sala-i-Martin 2004; Romer 2007). What does this evidence mean for Africa-Europe STI cooperation, in the face of global challenges such as climate change, food security and human health? Apart from considering STI as an engine of growth, the EU has an interest in the creation of markets for its products in Africa, where competition from China, Japan and India is increasingly being felt. Economic growth and employment creation in Africa are also likely to ease the migration pressures EU countries are presently facing. In the event of higher growth, job creation and economic stability in Africa, as well as better adaptation to climate change, the anticipated need for recurring emergency relief operations will be reduced, as will be the threat of tropical diseases through the development of new medicines and vaccines, clinical trials and laboratory experiments. For the EU, these are among some clear and unequivocal reasons to cooperate.

Many African countries have recorded impressive economic growth rates in recent years, but this growth is likely to taper off unless buttressed by genuine economic transformation and technological advances (Booth and Therkildsen 2012). Cooperation between Africa and Europe can help both sides to achieve their objectives more effectively and efficiently than if they work in isolation from each other. However, more attention is required to address several systemic and structural challenges that tend to limit the continents' ability to effectively participate in R\&I cooperation with the EU and the rest of the world (Barugahara and Tostensen 2009a). To ameliorate this situation, resources need to be leveraged in order to strengthen the capacity of African institutions and researchers to become effective and genuine partners with their EU counterparts in building robust STI systems across Africa, and in the EU. More effort is required to augment the existing Africa-EU collaborations, including CAAST-Net Plus which designed and implemented a series of research capacity building events to complement the work of related initiatives such as AfricaLics, whose secretariat is based at the African Centre for Technology Studies (ACTS) in Kenya, and the DfiD-funded Climate Impacts Research Capacity and Leadership Enhancement (CIRCLE) programme, implemented by the African Academy of Sciences. Policymakers therefore need to place 
greater emphasis on creating incentives and building adequate network infrastructure and human resource capacities that are required for effective participation in international cooperation activities.

\section{Financing Cooperation}

The appropriate modality of financing for various EU and African STI initiatives should involve a mix at multiple levels. The current practice with direct funding of national activities alongside funding through the RECs as well as through continental bodies may facilitate budgetary control and cost-effectiveness. Mechanisms should be put in place to ensure harmonisation of interventions at various levels for greater development impact and uptake of research findings with more efficient use of resources.

Specific project support measures for short-term research and/or development activities in the mutual EU-Africa STI priorities as given in the JAES should be emphasised. Longer-term and sustainable funding arrangements might be established through, for example, regional financial institutions such as the African Development Bank for regional and continent-wide STI initiatives, complemented by funding sources at the national level. Proposals towards that end have been mooted in several fora and need to be reinforced and made operational.

\section{Bridging the Gap Between Science and Global Development}

The world is facing formidable development challenges, above all reducing poverty and food insecurity. Meeting those challenges are the overarching objectives of development cooperation, and STI is a critical means to reach them. Although this book deals with bi-regional cooperation in STI, such cooperation is not an end in itself. It is indeed a means to an end. Hence, STI endeavours must be considered in conjunction with development efforts. So the uptake and application of research results is pivotal.

There is a plethora of policies and instruments related to STI, on the one hand, and development issues, on the other-at both EU and AU ends. Those policies and instruments need to be integrated into a coherent whole with a view to informing and underpinning development efforts with technologies stemming from research projects. This is not an easy task. Bridging the gap between STI and development efforts has been the subject of a long-standing and continuing discussion (e.g., Court et al. 2005; Leach et al. 2008). 
A permanent forum for Africa-Europe dialogue was established in 2014 with the HLPD on STI and the adoption of a roadmap for cooperation. The regular College-to-College meetings serve the same purpose of ensuring political commitment and technical follow-up on the implementation of the strategy. These fora will provide the needed follow-up of the policy aspirations of the continental authorities and provide an arena for professional interaction among policymakers, technocrats and development practitioners across Africa and the EU as an essential first step towards bridging the gap between science and global development (Barugahara and Tostensen 2009b; Diyamett 2008).

The relative importance and priority (in terms of resource envelopes) accorded to research as distinct from development activities requires conceptual attention. While debate is rife between proponents of both aspects, it should be noted that the road from research to products on the market shelf is not as straightforward (or "linear") as it may seem in the case of development interventions. Taking this into consideration, a greater appreciation of the uncertainties of research endeavours is required when balancing the funding priorities between STI and development interventions. Sustainable and adequate funding mechanisms could be explored within the development cooperation instruments with assurance for higher returns from investments in R\&I in the longer-term perspective.

The interface between STI and development efforts requires the building of operational models for bridging the existing gap. The models of collaboration between policymakers, scientists and practitioners with a view to achieving a greater uptake of research findings for development ends are essential components of development cooperation. This is only possible if the models are workable; that is, involving all relevant stakeholders operating on a common understanding and within a policy environment conducive to such collaboration. It would probably not be possible to arrive at a generic collaborative model that would fit all circumstances and sectors. Hence, most models, while replicable in some respects, will need to be "customised" to the specific conditions at hand, be they institutional or otherwise. ERAfrica is a new platform for research collaboration between Africa and Europe, co-funded by the EU and the collaborating partners, at a ratio of 20:80. The ERAfrica and the associated LEAP-Agri project model might herald the establishment of such innovative and viable models of development cooperation. Greater emphasis should be placed on the application aspects of Horizon 2020 projects in order to enhance the uptake of research outputs. 


\section{Conclusion}

The socio-political, humanitarian, economic, and technological drivers of Africa-Europe cooperation are well articulated in the ECD (2006), the CPA (NEPAD 2006), the JAES (African Union \& European Union 2007a) and the STISA-2024. Encompassing the aspirations of the two continents in development and STI, these policy documents constitute key elements of Africa-Europe cooperation. All of these frameworks note the challenges ahead, especially relating to the digital and economic divides between the two continents that characterise the cooperation landscape. Moreover, closing the existing digital and economic divides between developed and developing economies lends itself to joint bi-regional efforts. Given the potential dividends of STI, dialogue and negotiation across many themes and sectors between the two continents have given rise to a number of policy initiatives and funding schemes to facilitate biregional collaboration in joint endeavours. Apart from basic research, emphasis is increasingly put on the application of findings towards meeting major global challenges such as food and nutrition security, health and climate change.

\section{REFERENCES}

African Union \& European Union. (2007a). The Africa-EU strategic partnership: A joint Africa-EU strategy. Available from: http://www.africa-eu-partnership. org/sites/default/files/documents/eas2007_joint_strategy_en.pdf. Accessed 8 May 2017.

African Union \& European Union. (2007b). First action plan (2008-2010) for the implementation of the Africa-EU strategic partnership. Available from: http:// www.africa-eu-partnership.org/sites/default/files/documents/jaes_action_ plan_2008-2010.pdf. Accessed 8 May 2017.

African Union \& European Union. (2010). Joint Africa-EU strategy: Action plan 2011-2013. Available from: http://www.africa-eu-partnership.org/sites/ default/files/documents/03-JAES_action_plan_en.pdf. Accessed 8 May 2017. Barro, R. J., \& Sala-i-Martin, X. (2004). Economic growth (2nd ed.). Cambridge: MIT Press.

Barugahara, I. N., \& Tostensen, A. (2009a). Science and technology for development: The institutional landscape in Africa and Europe. Available from: https:// caast-net-plus.org/object/document/83/attach/ScienceandTechnology forDevelopment-1.pdf. Accessed 9 May 2017. 
Barugahara, I. N., \& Tostensen, A. (2009b). Towards better synergy between SerT and development: Proposals and recommendations. Available from: https:// caast-net-plus.org/object/document/73/attach/2_2_1_Towards_Better_ Synergy-2.pdf. Accessed 9 May 2017.

Booth, D., \& Therkildsen, O. (2012). The political economy of development in Africa: A joint statement from five research programmes. Available from: https://differenttakeonafrica.files.wordpress.com/2012/04/joint-statement. pdf. Accessed 9 May 2017.

Court, J., Hovland, I., \& Young, J. (Eds.). (2005). Bridging research and policy in development: Evidence and the change process. London: Overseas Development Institute.

Diyamett, B. D. (2008). Scientific community, relationship between science and technology and the African predicament: Who is to blame and what can be done? Available from: https://smartech.gatech.edu/bitstream/handle/1853/35621/Bitrina_ Diyamett_Scientific_Community.pdf?sequence=1\&isAllowed=y. Accessed 9 May 2017.

EU-Africa Summit. (2014). Fourth EU-Africa summit 2-3 April 2014, Brussels, roadmap 2014-2017. Available from: http://www.africa-eu-partnership.org/ sites/default/files/documents/2014_04_01_4th_eu-africa_summit_roadmap_en.pdf. Accessed 9 May 2017.

European Commission. (2006). The European consensus on development. Available from: https://ec.europa.eu/europeaid/sites/devco/files/publication-theeuropean-consensus-on-development-200606_en.pdf. Accessed 9 May 2017.

European Commission. (2016a). Press release: Joint communique between the African Union Commission and the European Commission at their 8th College to College Meeting. Available from: http://europa.eu/rapid/press-release_ STATEMENT-16-1301_de.htm. Accessed 9 May 2017.

European Commission. (2016b). Press release: African Union Commission and European Commission meet to address shared EU-Africa challenges. Available from: http://europa.eu/rapid/press-release_IP-16-1226_en.htm. Accessed 9 May 2017.

European Commission. (2016c). Implementation of the strategy for international cooperation in research and innovation. Available from: https://www.ffg.at/ sites/default/files/downloads/progress_report_oct-2016.pdf. Accessed 8 June 2017.

European Commission. (2017). Joint communication to the European Parliament and the Council for a renewed impetus of the Africa-EU partnership. Available from: http://www.africa-eu-partnership.org/sites/default/files/documents / communication_for_a_renewed_impetus_of_the_africa-eu_partnership.pdf. Accessed 8 June 2017.

European Union. (2015). Briefing. EU scientific cooperation with third countries. European Parliamentary Research Service. Available from: http:// www.europarl.europa.eu/RegData/etudes/BRIE/2015/564393/EPRS_ BRI(2015)564393_EN.pdf. Accessed 26 June 2017. 
Leach, M., Sumner, A., \& Waldman, L. (2008). Discourse, dynamics and disquiet: Multiple knowledge in science, society and development. Journal of International Development., 20(6), 727-738.

NEPAD. (2014). On the wings of Innovation: Science, technology and innovation for Africa 2024 Strategy (STISA-2024). Pretoria: NEPAD. Available from: http:// www.hsrc.ac.za/en/events/seminars/science-tech-and-innovation-strategy. Accessed 16 May 2017.

NEPAD Office of Science and Technology. (2006). Africa's science and technology: Consolidated plan of action (CPA). Available from: http://nepadwatercoe. org/wp-content/uploads/report_activities_cpa.pdf. Accessed 9 May 2017.

Romer, P. M. (2007). Economic growth. In The concise encyclopaedia of economics. Indianapolis: Liberty Fund.

Solow, R. M. (1956). A contribution to the theory of economic growth. Quarterly Journal of Economics., 70(1), 65-94.

Temple, J. (1999). The new growth evidence. Journal of Economic Literature., $37(1), 112-156$.

United Nations. (2015). Transforming our world: The 2030 Agenda for Sustainable Development. Available from: https://sustainabledevelopment.un.org/content/documents / $21252030 \% 20$ Agenda $\% 20$ for $\% 20$ Sustainable $\% 20$ Development\%20web.pdf. Accessed 9 May 2017.

Open Access This chapter is licensed under the terms of the Creative Commons Attribution 4.0 International License (http://creativecommons.org/licenses/ by $/ 4.0 /)$, which permits use, sharing, adaptation, distribution and reproduction in any medium or format, as long as you give appropriate credit to the original author(s) and the source, provide a link to the Creative Commons license and indicate if changes were made.

The images or other third party material in this chapter are included in the chapter's Creative Commons license, unless indicated otherwise in a credit line to the material. If material is not included in the chapter's Creative Commons license and your intended use is not permitted by statutory regulation or exceeds the permitted use, you will need to obtain permission directly from the copyright holder.

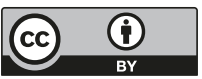

